\title{
Antimicrobial effect of turmeric (Curcuma longa) on chicken breast meat contamination
}

\section{-Author(s)}

Lourenço TC

Mendonça $\mathrm{EP}^{2 *}$

Nalevaiko PC

Melo $\mathrm{RT}^{3}$

Silva $\mathrm{PL}^{4}$

Rossi DA

DVM

2 Ph.D. student of the Post-Graduation Program in Veterinary Sciences, Universidade Federal de Uberlândia (UFU), Brazil

3 M.Sc. student of the Post-Graduation Program in Veterinary Sciences, UFU, Brazil

4 Prof. Dr., School of Veterinary Medicine, UFU, Brazil

5 Prof. Dr.,

\section{ABSTRACT}

The aim of this study was to evaluate the efficacy of turmeric (Curcuma longa), also known in Brazil as saffron, on the reduction of Staphylococcus aureus and Escherichia coli counts in chicken meat. Forty breast meat samples were divided in two groups (A and B). In group $A$, $10^{3}-10^{4}$ E. coli (ATCC 25922) cells were inoculated and group B samples were inoculated with $10^{4}-10^{5} \mathrm{~S}$. aureus (ATCC 9801) cells, after which each group was divided in three samples. The first sample was analyzed immediately after inoculation. The second sample (control group) was stored at $4{ }^{\circ} \mathrm{C}$ for 48 hours and turmeric at $1 \%(\mathrm{w} / \mathrm{w})$ was added to the third sample, which was homogenized and then stored under the same conditions as the second sample. E. coli and S. aureus were enumerated in all samples. Mean bacterial counts determined for the control samples and for the samples with turmeric addition after $48 \mathrm{~h}$ of storage were $1.83 \times 10^{4} \mathrm{CFU} \mathrm{g}^{-1}$ and $1.80 \times 10^{4} \mathrm{CFU} \mathrm{g}^{-1}$ for S. aureus, and $9.36 \times$ $10^{3} \mathrm{CFU} \mathrm{g}^{-1}$ and $7.25 \times 10^{3} \mathrm{CFU} \mathrm{g}^{-1}$ for $E$. coli, respectively. The results showed that there was no significant reduction in bacterial counts with the addition of $1 \%$ turmeric to chicken breast meat.

\section{INTRODUCTION}

The microbial contamination of foods is an important public health concern, and consequently, it is also influences economy. The poultry industry, for instance, faces difficulties in the control of the contamination of broiler carcasses, which negatively influences food safety and reduces food shelf life (Capita et al., 2001).

Different pathogens have been isolated from chicken meat and have been involved in foodborne diseases, such as Escherichia coli (Moreira et al., 2005) and Staphylococcus aureus enterotoxin (Freitas et al., 2004). Consequently, chemical preservatives have been increasingly used in the processing industry to control microorganism levels in foods.

On the other hand, consumers have demanded from the food companies the application of practices to reduce the levels of chemical additives in food products, as many food preservatives have harmful side effects, including carcinogenic activity (Moreira et al., 2005). This has led to the search of natural alternatives for food preservation, minimizing consumers' health hazards (Souza et al., 2003). The study and assessment of antimicrobial activity in natural products, such as spices, have been stimulated with the aim of finding new options for the replacement of chemical preservatives to control the growth of foodborne pathogens (Coutinho et al., 2003).

An alternative to minimize poultry carcass contamination and that also functions as a condiment and enhances meat appearance and its acceptance in the market is the use of turmeric. Bara \& Vanetti (1992) reported that turmeric inhibited the development of pathogenic 
microorganisms, suggesting that its use in broiler carcasses may, in addition of providing it with a desirable yellow color, it may reduce carcass contamination by pathogenic microorganisms. Experiments show that a turmeric compound called curcumin is capable of inhibiting carcinogenesis (Chuang et al., 2000).

Therefore, this study aimed at evaluating the efficacy of turmeric in the reduction of Escherichia coli and Staphylococcus aureus counts in chicken breast samples.

\section{MATERIALS AND METHODS}

\section{Location and procedures}

The experiment was carried out at the Applied Animal Biotechnology Laboratory (Laboratório de Biotecnologia Animal Aplicada-LABIO) of Universidade Federal de Uberlândia, state of Minas Gerais, Brazil.

Forty chicken meat samples were acquired at a local retail store, divided in two groups, and experimentally contaminated with $10^{3}-10^{4}$ cells of Escherichia coli ATCC 25922 (group A) and $10^{4}-10^{5}$ cells of Staphylococcus aureus ATCC 9801 (group B).

Meat was cut in small pieces and samples weighing $400 \mathrm{~g}$ were then contaminated with the inoculum diluted in $5 \mathrm{~mL}$ sterile $\mathrm{NaCl}$ solution at $0.9 \%$. Samples and inocula were homogenized for five minutes. After contamination, groups A and B were aseptically divided, using laminar flow, in three samples weighing approximately $100 \mathrm{~g}$, which were then identified and individually placed in sterile polyethylene bags. Sample 1 was immediately analyzed for $E$. coli and S. aureus enumeration, and sample 2 (control group) was stored

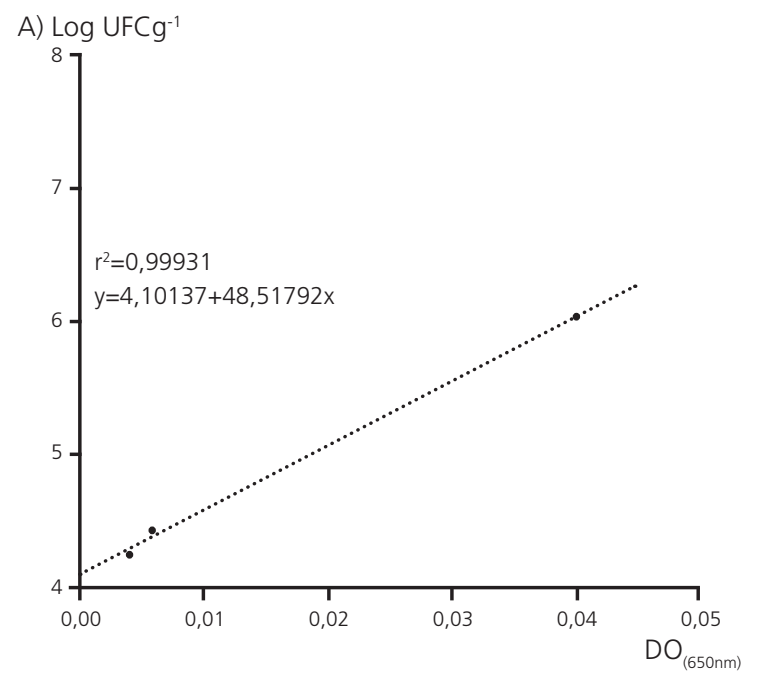

under refrigeration $\left(4^{\circ} \mathrm{C}\right)$ for $48 \mathrm{~h}$. One percent $(\mathrm{w} / \mathrm{w})$ turmeric was added to sample 3 (test group), which was then homogenized, and stored under the same conditions as subsample 2. After the storage period, samples 2 and 3 were analyzed for $E$. coli and $S$. aureus enumeration.

Results were analyzed according to an individualized block experimental design, with two treatments of five replicates, totaling 40 experimental units. Microbiological counts were submitted to analysis of variance and means were compared by the test of Tukey (Triola, 1999).

\section{Inoculum standardization}

The inoculum was standardized by monitoring during several incubation periods. Optical density at $650 \mathrm{~nm}\left(\mathrm{OD}_{650 \mathrm{~nm}}\right)$ was correlated with the number of colony-forming units $\left(\mathrm{CFUg}^{-1}\right)$, using a regression equation by means of the software program MicroCal ORIGIN 4.0 (1995). The equation was used to predict and to standardize the number of inoculated cells.

\section{Microbiological analyses}

Out of each sample, $25 \mathrm{~g}$ were analyzed. Samples were added to $225 \mathrm{~mL}$ buffered peptone water at $0.1 \%$ (BPW), which was considered $10^{-1}$ dilution, based on which serial dilutions in BPW were performed. Escherichia coli (CFU. ${ }^{-1}$ ) and Staphylococcus aureus (CFU.g ${ }^{-1}$ ) were then enumerated using the Simplate chromogen method (Franco \& Landgraf, 1996) and inoculation in Baird Parker agar (ABNT, 1991), respectively.

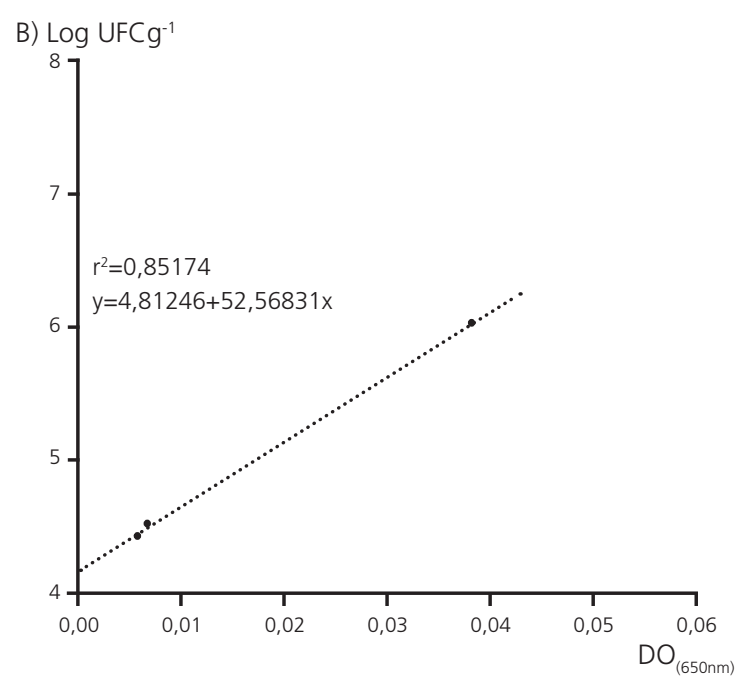

Figure 1. Regression equation, graph, and coefficient of correlation for Escherichia coli ATCC 25922 (A) and Staphylococcus aureus ATCC 9801 (B) obtained by optical density at $650 \mathrm{~nm}\left(\mathrm{OD}_{650 \mathrm{~mm}}\right)$ and $\mathrm{CFUg}^{-1}$ logarithm. 


\section{RESULTS AND DISCUSSION}

The results obtained for optical density at $650 \mathrm{~nm}$ $\left(\mathrm{OD}_{650 \mathrm{~nm}}\right)$ and colony-forming units $\left(\mathrm{CFUg}^{-1}\right)$ of Escherichia coli ATCC 25922 and Staphylococcus aureus ATCC 9801 were used to build the regression equation and graph (Figure 1 - A and B).

Sample 1, immediately after inoculation, presented Escherichia coli ATCC 25922 counts between 7.4 x $10^{3} \mathrm{CFU} \mathrm{g}^{-1}$ and $2.1 \times 10^{4} \mathrm{CFU} \mathrm{g}^{-1}$, and Staphylococcus aureus ATCC 9801 counts between $2.3 \times 10^{4}$ CFU.g ${ }^{-1}$ and $1.1 \times 10^{5} \mathrm{CFU} \mathrm{g}^{-1}$ (Table 1).

Table 1 - Escherichia coli ATCC 25922 and Staphylococcus aureus ATCC 9801 counts in chicken breast meat immediately after inoculation.

\begin{tabular}{lcc}
\hline \multirow{2}{*}{ Replicate } & \multicolumn{2}{c}{ CFU g $^{-1}$ calculation } \\
\cline { 2 - 3 } & E. coli ATCC $\mathbf{2 5 9 2 2}$ & S. aureus ATCC 9801 \\
\hline 1 & $1.1 \times 10^{4}$ & $5.0 \times 10^{4}$ \\
2 & $7.4 \times 10^{3}$ & $9.7 \times 10^{4}$ \\
3 & $2.0 \times 10^{4}$ & $2.3 \times 10^{4}$ \\
4 & $2.1 \times 10^{4}$ & $1.1 \times 10^{5}$ \\
5 & $2.0 \times 10^{4}$ & $9.5 \times 10^{4}$ \\
\hline
\end{tabular}

The obtained counts indicate the applied calculations were adequate for the artificial contamination of chicken meat samples with $E$. coli and $S$. aureus. These results are in agreement with the recommendations of Jorge et al. (1990) of using a regression equation (OD vs. CFU.g-1) as a tool to standardize experimental inocula.

Mean Staphylococcus aureus counts determined in samples of the control group and of the test group were $1.83 \times 10^{4} \mathrm{CFU} \mathrm{g}^{-1}$ and $1.80 \times 10^{4} \mathrm{CFU} \mathrm{g}^{-1}$, respectively. These counts indicate that the use of turmeric did not reduce ( $p>0.05$ ) S. aureus contamination after $48 \mathrm{~h}$ of contamination. These results are presented in Table 2 .

Table 2 - Staphylococcus aureus and Escherichia coli counts $\left(\mathrm{CFU} . \mathrm{g}^{-1}\right)$ in chicken breast meat with the addition or not of $1 \%$ turmeric in after refrigeration at $4^{\circ} \mathrm{C}$ for 48 hours.

\begin{tabular}{|c|c|c|c|c|}
\hline \multirow[b]{2}{*}{ Replicate } & \multicolumn{2}{|c|}{ S. aureus count } & \multicolumn{2}{|c|}{ E. coli count } \\
\hline & No turmeric & $\begin{array}{c}\text { With } \\
\text { turmeric }\end{array}$ & $\begin{array}{l}\text { No } \\
\text { turmeric }\end{array}$ & $\begin{array}{c}\text { With } \\
\text { turmeric }\end{array}$ \\
\hline 1 & $2.0 \times 10^{4}$ & $1.9 \times 10^{4}$ & $8.4 \times 10^{3}$ & $4.8 \times 10^{3}$ \\
\hline 2 & $1.9 \times 10^{4}$ & $2.2 \times 10^{4}$ & $4.4 \times 10^{3}$ & $8.6 \times 10^{2}$ \\
\hline 3 & $1.4 \times 104$ & $1.5 \times 10^{4}$ & $1.7 \times 10^{4}$ & $1.2 \times 10^{4}$ \\
\hline 4 & $2.6 \times 10^{4}$ & $1.6 \times 10^{4}$ & $7.0 \times 10^{3}$ & $5.0 \times 10^{3}$ \\
\hline 5 & $1.3 \times 10^{4}$ & $1.8 \times 10^{4}$ & $1.0 \times 10^{4}$ & $1.4 \times 104$ \\
\hline $\begin{array}{l}\text { Mean counts in } \\
\text { CFU.g- }\end{array}$ & $1.83 \times 10^{4} \mathrm{a}$ & $1.80 \times 10^{4} a$ & $9.36 \times 10^{3} \mathrm{a}$ & $7.25 \times 10^{3} \mathrm{a}$ \\
\hline $\begin{array}{l}\text { Mean counts in } \\
\log ^{10}\end{array}$ & $\begin{array}{c}4.249774 \\
a \\
\end{array}$ & $\begin{array}{c}4.251332 \\
a \\
\end{array}$ & $\begin{array}{c}3.929994 \\
a \\
\end{array}$ & $\begin{array}{c}3.705486 \\
a \\
\end{array}$ \\
\hline $\begin{array}{l}\text { Coefficient of } \\
\text { variation (\%) }\end{array}$ & \multicolumn{2}{|c|}{2.32} & \multicolumn{2}{|c|}{9.71} \\
\hline
\end{tabular}

a Means followed by the same letter in the same row are not statistically different ( $p>0.05$ ) CFU. $g^{-1}$ : colony-forming unit per gram
Ferreira (2003) also did not observe any significant reduction in $S$. aureus counts in cottage cheese samples treated with powdered turmeric at $0.2 \%$, $0.4 \%, 0.8 \%$, or $1.0 \%$ However, when 2.0 to $6.0 \%$ were used, an antimicrobial effect was detected. On the other hand, Franco et al. (2007) evaluated the possible antimicrobial effect of Curcuma longa $\mathrm{L}$. essential oil on Staphylococcus aureus ATCC 6538, Escherichia coli 0:158 and Salmonella choleraesuis ATCC 10708 growth using agar diffusion, and verified that only S. aureus ATCC 6538 growth was inhibited. Those authors suggested that turmeric may specifically act against Gram-positive bacteria.

There was no influence $(p<0.05)$ on the addition of turmeric to the chicken breast meat samples on $E$. coli counts in the present experiment. Mean E. coli counts obtained in samples without or with turmeric addition were $9.36 \times 10^{3} \mathrm{CFU} . \mathrm{g}^{-1}$ and $7.25 \times 10^{3} \mathrm{CFU}^{-1}{ }^{-1}$, respectively, as shown in Table 2 .

According to Shelef (1980), the concentration of turmeric required to inhibit bacterial growth is between 1 and $5 \%$, which may explain the lack of effect on $E$. coli and S. aureus in the present experiment, where low turmeric concentration was applied. Moreover, this concentration was not sufficient to inhibit the high number of microorganisms (104) inoculated. However, considering that the typical levels of turmeric used to enhance food flavor and aroma are in the range of 0.5 to $1 \%$, higher levels may impair consumer acceptance. Therefore, the optimal turmeric concentration, which simultaneously has antimicrobial and flavor enhancement effects, needs to be determined.

Because turmeric components are nonpolar and chicken meat is rich in water and not in fats the applied turmeric powder did not present proper solubility, which may have influenced its antibacterial action.

\section{CONCLUSIONS}

The growth of Staphylococcus aureus and Escherichia coli was not inhibited in chicken meat breasts treated with $1 \%$ powdered turmeric.

\section{REFERENCES}

Associação Brasileira de Normas Técnicas. Contagem de Staphylococcus aureus em placas. MB3463. Rio de janeiro; 1991.

Bara MTF, Vanetti MCD. Atividade antimicrobiana de corantes naturais sobre microrganismos patogênicos veiculados por alimentos. Revista Brasileira de Corantes Naturais 1992;1(1):194-200.

Capita R, Alonso-Calleja C, García-Fernández MD, Moreno B. Microbiological quality of retail poultry carcasses in Spain. Journal of Food Protection 2001;64(12):1961-1966. 
Chuang SE, Cheng AL, Lin JK, Kuo ML. Inhibition by curcumin of diethylnitrosamine-induced hepatic hyperplasia, inflammation, cellular gene products and cell-cycle-related proteins in rats. Food and Chemical Toxicology 2000;38(11):991-995.

Coutinho HDM, Bezerra DAC, Lobo K, Barbosa IJF. Atividade antimicrobiana de produtos naturais. Conceitos 2003;77:77-85.

Farag RS, Daw ZY, Abo-Raya SH. Influence of Some spice essential oils on Aspergillus parasiticus growth and production of aflatoxins in a synthetic medium. Journal of Food Science 1989;54:74-76.

Ferreira AC. Uso do açafrão (Curcuma longa) no controle de Staphylococcus aureus em ricota [dissertação]. Lavras (MG): Universidade Federal de Lavras; 2003.

Franco ALP, Oliveira TB, Ferri PH, Bara MTF, Paula JR. Avaliação da composição química e atividade antibacteriana dos óleos essenciais de Aloysia gratissima (Gillies \& Hook) Tronc. (Alfazema), Ocimum gratissimum L. (Alfavaca-cravo) e Curcuma longa L. (Açafrão). Revista Eletrônica de Farmácia 2007;4(2):208-220.

Franco BDGM, Landgraf M. Microbiologia dos alimentos. São Paulo: Atheneu; 1996.

Freitas MFL, Leão AEDS, Stamford TLM, Mota RA. Ocorrência de Staphylococcus aureus em carcaças de frango. Boletim do Centro de Pesquisa de Processamento de Alimentos 2004;22(2): 271-282.

Jorge AOC, Vieira S, Holfling JF, Almeida OP. Determinação da dose letal $50 \%$ para Staphylococcus aureus (NCTC 8530) em camundongos portadores de tumor de Erlich. Revista de Microbiologia 1990;3(21):228-231.

MICROCAL ORIGIN. Origin version 4.0. Northamp: Microcal Software; 1995

Moreira MR, Ponce AG, Del Valle CE, Roura SI. Inhibitory parameters of essential oils to reduce a foodborne pathogen, LWT-Food Science and Technology 2005;38(5):565-570.

Pruthi JS. Spices and condiments: chemistry, microbiology and technology. New York: Academic Press; 1980.

Shelef LA, Naglik OA, Bogen DW. Sensitivity of some common food-borne bacteria to the spices sage, rosemary and allspice. Journal of Food Science 1980;45(4):1042-1044.

Souza EL, Lima EO, Narain N. Especiarias: uma alternativa para o controle de qualidade sanitária e de vida útil de alimentos, frente às novas perspectivas da indústria alimentícia. Higiene alimentar 2003;17(113):38-42.

Triola MF. Introdução à estatística. 7ª ed. Rio de janeirio: Editora LTC; 1999. 